\title{
Chapter 3: The Political Viability of Federal Reform: Interpreting Public Attitudes
}

\author{
Ian Gray and A. J. Brown
}

\section{Introduction}

Does 'regionalism' have a popular basis in Australian political culture? When mapping possibilities for the future of Australian federalism, what is the contemporary 'realm of the possible' in terms of political support for reform to address long term deficits in regional governance? These questions are fundamental to understanding where current tensions and trends are leading the federal system. As outlined in the preceding chapters, and shown by many that follow, Australian federalism is not static - in response to diverse pressures, it is shifting and facing new institutional developments. But which options are recognisable by the larger community, which have their support, and which are sustainable? When it comes to institutional strategies for making and delivering better public policy at a community level, which might have greater success or durability if they did resonate more strongly with citizen preferences? How much support exists for institutional restructuring, and where in our community is it based?

Understanding public opinions about Australian federalism is important, not only for answers to these practical questions, but because many political leaders and commentators presume that if it exists at all, public awareness of federalism is unsophisticated. A leading analyst, Brian Galligan, suggests we should resign ourselves to a permanent state of popular disaffection with the federal system, predicting there will probably always be 'critics calling for its abolition' even though 'abolitionist scenarios are for idle speculators' (Galligan 1995: 61, 253). These observations recognise the regularity with which public debate returns to the question of whether federalism needs major restructuring, if not through the creation of new states as once envisaged under the Constitution, then through the replacement of all states with alternative regional governments. Even Australia's second longest serving Prime Minister can be found among the 'speculators', having said that if you were starting Australia all over again you would have a national government and 20 regional governments' (Howard 1991); 'if we had our time again, we might have organised ourselves differently' (Howard 2005). Nevertheless, John Howard, like Brian Galligan, agrees we do not have this luxury, and retreats to the view this would now be an 'empty theoretical exercise' (Howard 2002) or 'pure theorising' (Howard 2005). But 
meanwhile, the debate refuses to go away, public criticism of federalism continues, and policy pressures continue to mount. As recently as March 2007, the Sydney Morning Herald recorded the following results to a snap on-line poll:

Our six states, who needs 'em? More than a century after federation, does Australia still need the States?

\begin{tabular}{|l|r|}
\hline Absolutely. Without the States local issues would be swamped by & $36 \%$
\end{tabular} Canberra.

Abolish them. They are a waste of taxpayers money.

Total Votes: 1789 (SMH 12 March 2007)

Do such calls for change amount to more than mere speculation, and by more closely examining them, can we now help inform a more coherent approach? This chapter seeks to make better sense of public opinion about the federal system using evidence from pilot surveys of random samples of Australian adults undertaken in Queensland in 2001 and, more recently, in New South Wales (NSW) in 2005. To better establish whether popular pressure for reform really only consists of idle speculation, these surveys have begun to explore the breadth of support for and change in the federal institutions, so as to better inform discussions about the institutional options that might be worth considering. The first survey, in September 2001, asked 301 Queensland adults about their attitudes to existing institutions and their expectations of, and preferences for, change or maintenance of the status quo (Brown 2002a, 2002b). In late 2005, these questions were repeated in a survey of 502 adults in of New South Wales, supplemented by more detailed questions on satisfaction with government and demographic data. This second study provides the bulk of analysis that follows, and was conducted by Griffith University's Federalism Project and Charles Sturt University's Centre for Rural Social Research with funding from a Griffith University Research Encouragement Grant, Charles Sturt University School of Humanities and Social Sciences and NSW Farmers' Association (see Brown, Gray and Giorgas 2006). ${ }^{l}$ These surveys have helped form the background to national attitudinal research, now in progress.

Both surveys were conducted by telephone with respondents selected at random from telephone listings, being the person aged over 18 years whose birthday came next in each household contacted. In both studies, to facilitate regional comparisons, rural regions were oversampled. In Queensland, this enabled comparative analysis of attitudes in Greater Brisbane and the Gold and Sunshine Coasts, against those of Southern Queensland, Central Queensland, and North Queensland (Brown 2002b). In the NSW survey, this enabled comparison between Greater Sydney, Hunter and New England, Illawarra and South East NSW, Western NSW, and the Riverina (Brown et al 2006: 294-7). In each case the results were also then re-weighted by area and age to give statistically accurate 
statewide results (indicated as (w) in the relevant tables below). In both studies, urban and metropolitan results proved just as interesting as rural ones, and are clearly of great political significance since it is these regions that contain the bulk of the voting population.

This chapter extends and reinforces some earlier findings from these studies, with particular reference to understanding the relationship between federalism and regionalism. The first part of the chapter examines the breadth of popular sympathy for change, and also its geographic distribution. These results confirm that Australians' appetite for some reform of federalism is not restricted to idle speculators and that for many - indeed for a majority of citizens - it appears to extend significantly beyond the realms of 'empty' political theorising. To better understand who holds the strongest views in support of change, the second part of the chapter compares those most and least satisfied with existing institutions and those favouring more radical preferences for the future, against all other respondents, in a bid to locate any major demographic or sociological differences. The results show that critical attitudes of federalism and more radical preferences for change - which are not necessarily directly related - are widespread features of Australian society and not readily confined to particular regions or social groups. Instead, more radical preferences for change prove most popular among those citizens most directly engaged in the economy (by way of employment), especially by way of government employment, as well as those most directly engaged in governance more generally through community organisations or committees. It seems not only that many more Australians are interested in reform than previously understood, but that many also expect it. Given the dynamic state of developments in governance, what does this suggest about the realms of 'the possible' for institutional reform?

\section{Idle speculation or a more general query? Federalism and public opinion in Queensland and NSW}

Ideally, Australians should not have a low opinion of their political system, or show themselves resigned to living with one they do not accept. Institutional systems are important to people's life chances, well-being and democratic participation. The responsiveness of the political system to globalisation and uneven development, particularly with respect to the prospects for different regions, is a current theme in international and Australian debate. Federal, state and local governments alike show their own attempts at being more regionally-responsive, and have always done so in different ways, at different times, to widely varying degrees. Debate about these processes is usually restricted to temporary changes in administrative rather than political arrangements. Does Australian public opinion show an appetite for a more lasting, structural solution to pressure for a more responsive system? 
The first major finding from the surveys is that citizens of Queensland and NSW are not overly depressed about the state of Australian democracy overall - but do currently hold a more critical opinion of federalism as an element of the political system, than they do of the system in general. Table 3.1 sets out how the respondents to each survey answered a general question about the way democracy works in Australia', with 78\% and 63\% of Queensland and NSW respondents respectively indicating themselves to be fairly or very satisfied. Notwithstanding the difference between the state results, this overall satisfaction is consistent with the results of major national surveys such as the Australian Survey of Social Attitudes, showing a stable $77.6 \%$ and $75.7 \%$ of respondents to be satisfied with the way democracy works in 2003 and 2005 respectively.

Against this broad satisfaction with democracy, how do we identify specific views about the federal system? Table 3.2 shows that this depends on the question asked. In Queensland, when asked about 'the way the federation currently works', an even higher number of respondents indicated they were satisfied - but this was a general way of asking the question, at the height of the 2001 Centenary of Federation. By contrast, NSW respondents were asked about their satisfaction with federalism as a 'system of government', defined as 'a three-tiered system of government, with federal, state and local governments.' For these respondents, satisfaction dropped from $63.1 \%$ (with democracy) to $50.3 \%$ (with the federal system), while dissatisfaction rose from $34.7 \%$ (with democracy) to $48.1 \%$ (with the federal system).

These results may indicate that NSW citizens have a more critical view of both democracy (and presumably also federalism) than citizens elsewhere. Regardless, the key result is the size and direction of the change in reported satisfaction among NSW respondents, when asked about the federal system as against democracy in general. These data confirm that the three-tiered system is sometimes viewed differently to the democratic system as a whole. What leads to this more critical view of the structures of federalism? While more qualitative and quantitative research is needed to answer this definitively, the present surveys go some way towards the answer by providing data both on: (1) the different relative levels of satisfaction that citizens feel in respect of each of the current tiers of government - federal, state and local; and (2) whether and how citizens would prefer the institutions of federalism to evolve. 


\section{Table 3.1. Satisfaction with democracy (Australia, Queensland, NSW)}

\begin{tabular}{|c|c|c|c|c|}
\hline & \multicolumn{2}{|c|}{ Australia \% } & \multirow[b]{2}{*}{$\begin{array}{l}\text { Queensland \% } \\
\text { 'On the whole, how } \\
\text { satisfied or } \\
\text { dissatisfied are you } \\
\text { with the way } \\
\text { democracy works in } \\
\text { Australia?' }\end{array}$} & \multirow[b]{2}{*}{$\begin{array}{l}\text { NSW \% (w) } \\
\text { 'Overall, how } \\
\text { satisfied are you } \\
\text { with the way } \\
\text { democracy currently } \\
\text { works in Australia?' }\end{array}$} \\
\hline & $\begin{array}{l}\text { 'How proud are you } \\
\text { of Australia in ... the } \\
\text { way democracy } \\
\text { works?' }\end{array}$ & $\begin{array}{l}\text { 'On the whole, ... } \\
\text { how well does } \\
\text { democracy work in } \\
\text { Australia today?' } \\
\text { [adapted from 0-10 } \\
\text { scale] }\end{array}$ & & \\
\hline Very & 24.5 & 37.2 & 10.0 & 12.3 \\
\hline Fairly & 53.1 & 38.5 & 68.0 & 50.8 \\
\hline Satisfied & 77.6 & 75.7 & 78.0 & 63.1 \\
\hline Not very & 13.0 & 13.7 & 13.0 & 24.8 \\
\hline Not at all & 2.7 & 4.7 & 7.0 & 9.9 \\
\hline Not satisfied & 15.7 & 18.4 & 20.0 & 34.7 \\
\hline No opinion & 6.8 & 6.0 & 2.0 & 2.1 \\
\hline Total & 100.0 & 100.0 & 100.0 & 100.0 \\
\hline Source: & $\begin{array}{l}\text { Australian Survey of } \\
\text { Social Attitudes } \\
2003(n=2130)\end{array}$ & $\begin{array}{l}\text { Australian Survey of } \\
\text { Social Attitudes } \\
2005(n=1889)\end{array}$ & $\begin{array}{l}\text { Qld survey } 2001 \\
(n=301)\end{array}$ & $\begin{array}{l}\text { NSW survey } 2005 \\
(n=502)\end{array}$ \\
\hline
\end{tabular}

\section{Table 3.2. Satisfaction with federalism (Queensland, NSW)}

\begin{tabular}{|c|c|c|c|c|}
\hline & \multirow{2}{*}{\multicolumn{2}{|c|}{$\begin{array}{l}\text { Queensland \% } \\
\text { ‘On the whole, how satisfied or dissatisfied } \\
\text { are you with the way ... } \\
\begin{array}{ll}\text {... democracy works ... the federation } \\
\text { in Australia?' } & \text { currently works in } \\
& \text { Australia?’ }\end{array}\end{array}$}} & \multicolumn{2}{|c|}{ NSW \% (w) } \\
\hline & & & $\begin{array}{l}\text { 'Overall, how } \\
\text { satisfied are you } \\
\text { with the way } \\
\text { democracy currently } \\
\text { works in Australia?' }\end{array}$ & $\begin{array}{l}\text { 'Australia has a } \\
\text { three-tiered system } \\
\text { of government, with } \\
\text { federal, state and } \\
\text { local governments. } \\
\text { Overall, how } \\
\text { satisfied are you } \\
\text { with the way this } \\
\text { system of } \\
\text { government currently y } \\
\text { works in Australia?' }\end{array}$ \\
\hline Very & 10.0 & 14.0 & 12.3 & 5.2 \\
\hline Fairly & 68.0 & 68.0 & 50.8 & 45.1 \\
\hline Satisfied & 78.0 & 82.0 & 63.1 & 50.3 \\
\hline Not very & 13.0 & 8.0 & 24.8 & 37.4 \\
\hline Not at all & 7.0 & 8.0 & 9.9 & 10.7 \\
\hline Not satisfied & 20.0 & 16.0 & 34.7 & 48.1 \\
\hline No opinion & 2.0 & 2.0 & 2.1 & 1.5 \\
\hline Total & 100.0 & 100.0 & 100.0 & 100.0 \\
\hline Source: & Qld survey $2001 \mathrm{ln}=$ & $=3011$ & NSW survey 2005 (n & $=502)$ \\
\hline
\end{tabular}


To establish the level of satisfaction with each existing tier of government, the NSW survey asked respondents in which of the three different governments they had most faith and confidence (Table 3.3) and how they would rate the performance of each of the different levels of government (Table 3.4). If the main basis of many respondents' dissatisfaction with current federalism was a feeling that the federal government was becoming too centralised, overpowerful or operating in areas beyond its competence, we would expect the federal government to rate poorly in response to both questions. Conversely, if the main basis of dissatisfaction was corruption, incompetence or under-capacity in Australia's comparatively weak system of local government, then that too should be discernable. However as the data show, the least faith and confidence, and poorest assessment of performance emerged in respect of the state level. Only $12.8 \%$ of respondents were prepared to rate the performance of the state level as 'good' or 'very good' - less than half the number prepared to rate either federal or local government in this way - with many more respondents convinced that the performance of state government was positively 'poor' compared to the other tiers. As set out in Table 3.5, the notion that it is the place and role of state governments that represents the weakest link in the present federal system, is confirmed by the strong correlation between those expressing the least satisfaction with the system overall, and those most critical of state governments.

\section{Table 3.3. Most faith and confidence in a level of government (NSW)}

'We find that people have different degrees of faith and confidence in the different governments that affect them directly. In your case, which do you have most faith and confidence in?'

\begin{tabular}{l|rr} 
& No. of respondents & \% of respondents \\
\hline The Federal Government & 205 & $40.9 \%$ \\
Your State Government & 125 & $24.9 \%$ \\
Your Local Government & 172 & $34.2 \%$ \\
\hline Total & 502 & $100.0 \%$ \\
\hline
\end{tabular}

\section{Table 3.4. Performance of different levels of government (NSW)}

'On a scale of 1 to 5 , how would you rate the performance of the different levels of government in Australia? 1 is very poor, 5 is very good.'

\begin{tabular}{l|rrr|r|r} 
& \multicolumn{5}{|c}{$\%$ of respondents } \\
\hline & $\begin{array}{r}\text { Very poor / } \\
\text { poor (1/2) }\end{array}$ & (3) & Good / very & No opinion & \\
The federal government & 34.3 & 36.2 & 28.1 & 1.4 & 100.0 \\
State governments & 51.0 & 34.0 & 12.8 & 2.2 & 100.0 \\
Local government & 38.1 & 34.7 & 26.0 & 1.2 & 100.0 \\
\hline
\end{tabular}




\section{Table 3.5. Performance of state government, by extremes of satisfaction with the federal system (NSW)}

\begin{tabular}{|c|c|c|c|c|c|}
\hline & \multicolumn{5}{|c|}{$\%$ of respondents } \\
\hline & $\begin{array}{r}\text { Very poor } / \\
\text { poor }(1 / 2)\end{array}$ & & $\begin{array}{r}\text { Good / very } \\
\text { good }(4 / 5)\end{array}$ & No opinion & \\
\hline $\begin{array}{l}\text { State government (as rated by all } \\
\text { respondents) }\end{array}$ & 51.0 & 34.0 & 12.8 & 2.2 & 100.0 \\
\hline $\begin{array}{l}\text { State government (respondents 'very } \\
\text { satisfied' with the current system of } \\
\text { government) }\end{array}$ & $\begin{array}{r}26.9 \\
(7)\end{array}$ & $\begin{array}{r}23.1 \\
(6)\end{array}$ & $\begin{array}{r}50.0 \\
(13)\end{array}$ & $\begin{array}{r}0.0 \\
(0)\end{array}$ & $\begin{array}{r}100.0 \\
(26)\end{array}$ \\
\hline $\begin{array}{l}\text { State government (respondents 'not } \\
\text { at all satisfied' with the current } \\
\text { system of government) }\end{array}$ & $\begin{array}{r}75.9 \\
(41)\end{array}$ & $\begin{array}{r}11.1 \\
(6)\end{array}$ & $\begin{array}{r}5.6 \\
(3)\end{array}$ & $\begin{array}{r}7.4 \\
(4)\end{array}$ & $\begin{array}{r}100.0 \\
(54)\end{array}$ \\
\hline
\end{tabular}

In some circumstances, this significantly greater disapproval of state government could simply reflect short-term unpopularity or falling legitimacy on the part of a particular elected government. However there is good reason to believe that no such simple explanation applies here. At the next NSW State Election, in March 2007, there was no change of government. More importantly, the survey asked respondents whether their views about faith and confidence in different levels of government would change 'if there was an election and the government changed, i.e. other politicians were in power'. Of those respondents indicating they had least faith in the federal government, $62.1 \%$ said that if the government changed, they would then hold either a 'somewhat different' or 'completely different' view. By contrast, this was true of only $48.3 \%$ of those respondents indicating they had least faith in the state government. In any event, even if the expressed disaffection with state government was partly party-political - as it no doubt was - this does not mean it could not also be partly 'constitutional' in nature, nor that at least some root causes of the expressed disaffection might not relate to institutional or structural problems even if the government of the day was inevitably to be blamed.

For these reasons, the questions in the survey dealing with expected and preferred constitutional outlook become important. In NSW, half the respondents $(50.3 \%)$ still indicated they were satisfied with the current three-tiered federal system. Accordingly, even if this confirms a high level of disaffection with current federal structures, the disaffection is clearly not total. If there are options for institutional restructuring that would improve the system, as canvassed through many of the chapters of this book, then their feasibility and acceptability will be determined as much by those who are currently reasonably satisfied with the system, not simply those who are not. Moreover, even citizens who are reasonably satisfied may also hold relevant views on these subjects, because they may also expect or desire change for the better, and may see new ways of doing business, without necessarily feeling positively disaffected with the current system. 
To establish how citizens expect and would prefer the basic institutions of federalism to evolve, both surveys asked respondents to choose which of four scenarios best described how they expected the federal system to look in another 50 to 100 years. A further question then asked respondents to choose which of the same four scenarios best described their preference for how the federal system should look in another 50 to 100 years. As explained elsewhere, these scenarios were not randomly generated but calculated to reflect some of the major alternatives suggested in the 'real world' of Australian political debate mentioned earlier (Brown 2001; 2002a; Brown at al 2006: 286-287; see also Brown this volume). The four scenarios, in order of presentation in the interviews, were:

a. retention of the status quo ('the same system as today');

b. the creation of new state governments on the existing three-tiered model;

c. a more general constitutional restructure replacing existing state and local governments with a new regional government framework;

d. the growth of a 'fourth tier' of regional institutions in addition to existing state and local governments.

Table 3.6 shows the results for both questions, for Queensland (2001) and NSW (2005). There are some differences because in the NSW survey, greater effort was made to elicit and separate responses 'other' than the offered scenarios, in addition to recording those who indicated 'no opinion' or 'don't know'. However there are similarities in the predictions made by respondents about how the federal system will look. Despite at least half the NSW respondents being satisfied with the current system, only $23.5 \%$ predicted that it would remain the same; along with $27 \%$ of respondents in Queensland. In both States, a clear majority - $63 \%$ of Queensland respondents and $64 \%$ of NSW respondents - showed a positive expectation of structural change in the federal system by choosing one of the nominated scenarios other than 'the same system as today' (i.e. not including 'others' and 'don't knows').

Table 3.6 and Figure 3.7 also show the Queensland and NSW results as to whether citizens would welcome such change. In Queensland, about the same number of respondents as expected the system to remain static, also preferred this outcome (although they were often not the same: see Brown 2002a). In NSW, the number who wished the system to remain the same fell to a lowly $12.5 \%$. In both States, a majority - 62\% in Queensland, and $74.2 \%$ in NSW - indicated they not only expect, but would prefer structural change. In each case, we can also see the total number of respondents who expect change whether or not they prefer it, or prefer it irrespective of whether they expect it to happen. In Queensland, this totalled at least $74 \%$ of all respondents; and in NSW, at least $79.9 \%$ of respondents. 
Table 3.6. Expected and preferred federal systems (Queensland 2001 and New South Wales 2005)

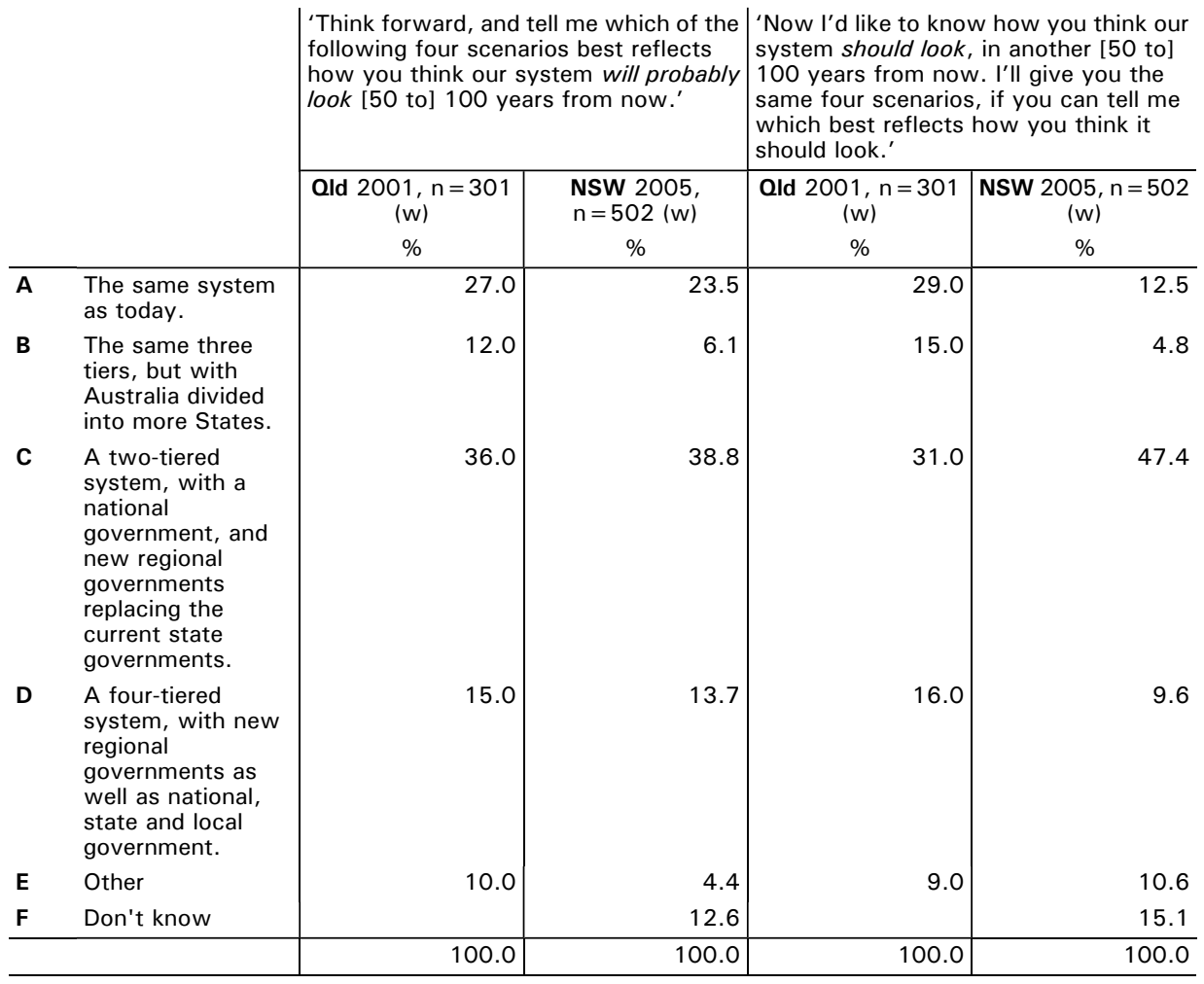

Figure 3.7, Preferred federal systems (Queensland and New South Wales)
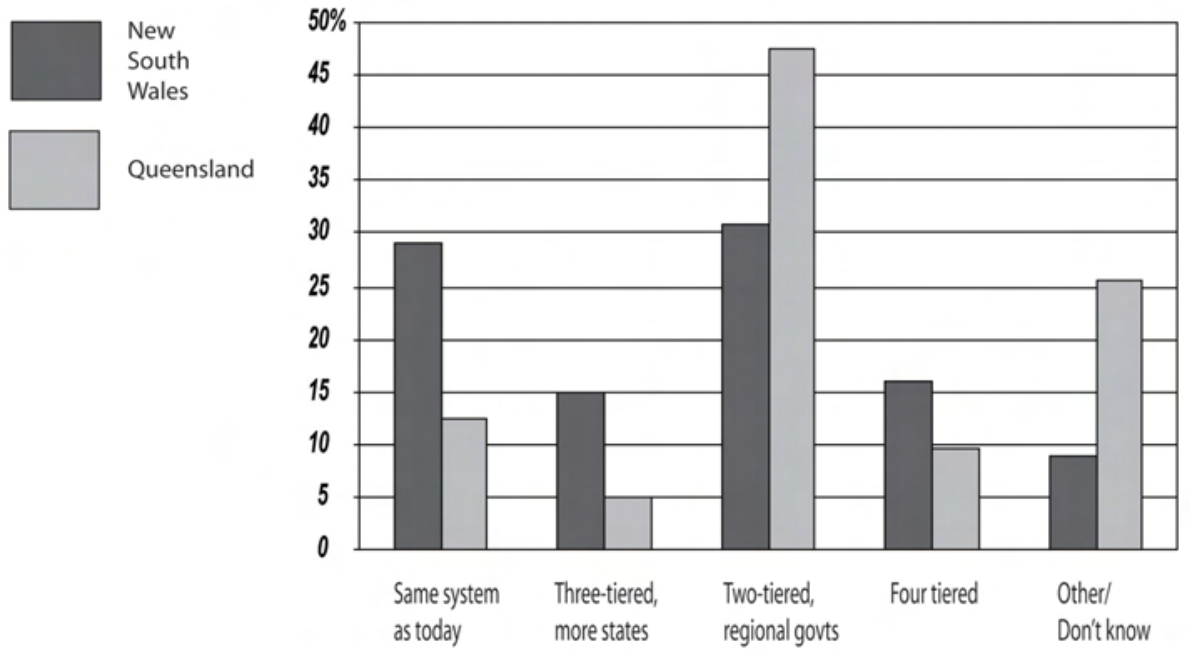
The relatively low proportion of 'don't know' responses is one indicator that citizens do have some grasp of the issues and hold at least some kind of view on these issues. However, research is ongoing in order to better establish how respondents interpret these scenarios, and whether they fairly represent citizens' expectations and preferences. For example, NSW respondents were also asked whether their concept of a 'two-tiered system' was one based on the amalgamation of local and current state administrations into new regional governments $(52.6 \%$ of respondents indicated this to be their preference), or one based on simple abolition of state governments leaving current local government as the second tier $(36.3 \%$ of respondents indicated this). Extrapolating from this, a further notional breakdown of future options is possible, as suggested in Figure 3.9 later in the chapter.

Nevertheless, an important result is the fact that many among the majority of respondents who envisage or desire change in the structure of federalism, did not express themselves to be positively dissatisfied with current arrangements. Table 3.8 confirms this, showing some more about the views of the $57 \%$ of NSW respondents who preferred the more radical scenarios, which involved new 'regional' governments instead of (scenario C) or in addition to (scenario D) the current States. These respondents were spread across the continuum in their satisfaction with the existing system, and were only slightly more likely than the remainder to criticise the current performance of state governments. The data, therefore, suggest not only that citizens are roughly evenly divided on the adequacy of the current system, but that even many of those who regard the current system as adequate, also envisage change and improvement. Indeed, the data suggest that many of these respondents, even if utopian, are not 'rosy eyed' about the prospects of change - although only $12.5 \%$ of respondents believed the status quo should remain, almost twice as many predict the status quo as the inevitable outcome.

\section{Table 3.8. Performance of state government, by preferred scenario (NSW)}

\begin{tabular}{|c|c|c|c|c|c|}
\hline & \multicolumn{5}{|c|}{$\%$ of respondents } \\
\hline & $\begin{array}{l}\text { Very poor I } \\
\text { poor }(1 / 2)\end{array}$ & (3) & $\begin{array}{l}\text { Good / very } \\
\text { good }(4 / 5)\end{array}$ & No opinion & \\
\hline $\begin{array}{l}\text { State government (as rated by all } \\
\text { respondents) }\end{array}$ & 51.0 & 34.0 & 12.8 & 2.2 & 100.0 \\
\hline $\begin{array}{l}\text { State government (respondents } \\
\text { preferring 'regional' scenarios C or D) }\end{array}$ & 54.8 & 33.7 & 10.4 & 1.0 & 100.0 \\
\hline $\begin{array}{l}\text { State government (all other } \\
\text { respondents) }\end{array}$ & 47.8 & 35.1 & 14.1 & 2.9 & 100.0 \\
\hline
\end{tabular}




\section{Looking for differences: what determines citizens' interest in change?}

Even if popular interest in the evolution of Australian federalism appears to be confirmed as a broad phenomenon rather than a maverick or fringe one, we need to know what sustains this interest, and what differentiates those convinced that change is desirable, from those content with the status quo. Are there particular features of these groups that would indicate their concerns might be addressed in other ways, not involving change to the federal system? Alternatively, even if institutional change provides a relevant part of the answer, are arguments for and against change deadlocked in a way that renders productive debate unlikely?

One of the most important questions is whether opinions differ significantly between rural and urban respondents. In NSW, as in Queensland, the history of regional agitation for political autonomy in the form of new states suggests that any interest in change should be concentrated in rural areas, remote from the State capitals. If there is rural interest in change, history also suggests this should take the relatively conservative form of a preference for more states, within the existing federal tradition. However as already discussed elsewhere, and demonstrated in Figure 3.9, the data show little difference between the major urban and rural regions in terms of preferred scenarios, as well as on other indicators (see Brown et al 2006: 292-7). This picture defies most previous political stereotypes. Interest in change is spread across urban and rural situations, and rural respondents were strongly in favour of a constitutional overhaul in which state governments were entirely replaced by new regional governments. As shown when the strong preference for a 'two-tiered' system is split between the two options mentioned earlier, rural respondents do appear to place a slightly higher value on existing local government, and on the option of retaining it as the basis of regional government. Again, however, the differences are marginal. Expectations and preferences for reform clearly span any urban-rural divide.

To look further for what distinguishes citizens' views, it is worth more closely examining the people who appear to have made up their minds, as indicated by those holding the apparently strongest views. In the New South Wales data, this is best indicated by looking at the 26 respondents $(5.2 \%)$ who indicated they were 'very satisfied' with the existing system, as against the 54 respondents $(10.7 \%)$ who indicated they were 'not at all' satisfied (Table 3.2 above). While the numbers in each group are small, they do help to identify a pattern. These groups were compared in Table 3.5, in respect of their rating of the performance of state governments. By further comparing two groups across a range of variables, we can look for or exclude various explanations of conservatism and radicalism with respect to federalism. 
Figure 3.9. Preferred federal systems, by major regions (NSW)

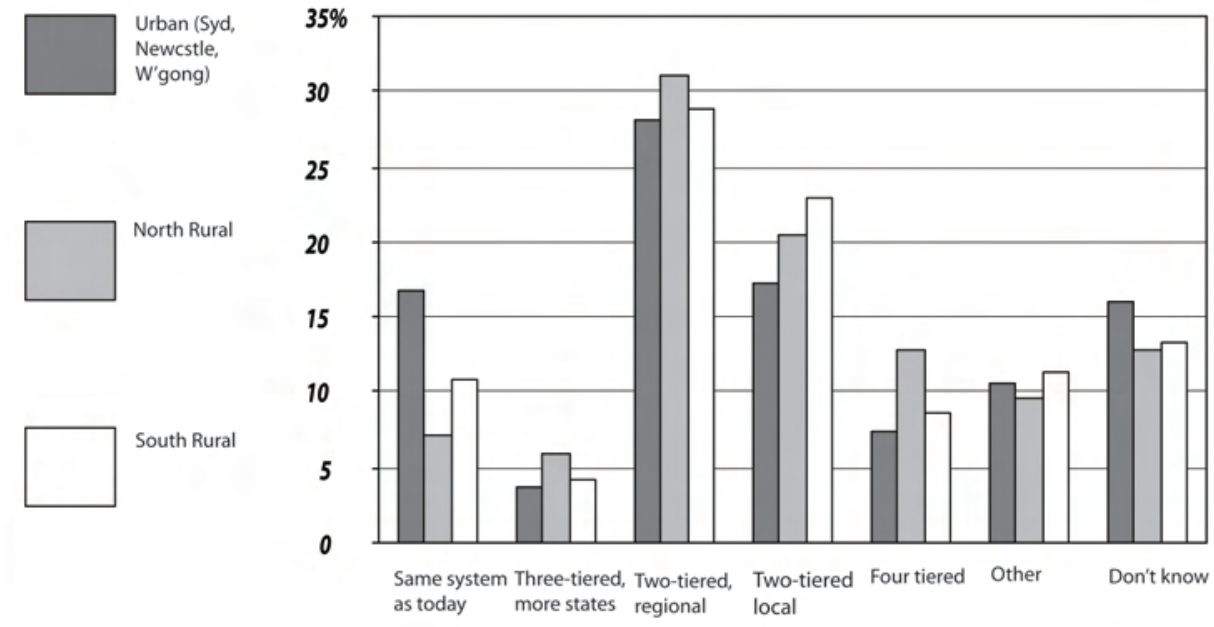

Firstly, strength of view does not appear to be related to gender (Table 3.10). The 26 most satisfied and the 54 least satisfied are equally divided among males and females. Tables 3.11 and 3.12 similarly indicate that period of current residence and level of education are unrelated to attitudes to federalism at their extremes. The only potentially significant indicators appear to be location, and age (Tables 3.13 and 3.14). As noted above, city-dwellers appear slightly more likely to prefer the status quo rather than scenarios involving change, and Table 3.13 shows that even though those expressing least satisfaction with the current system are divided equally between urban and rural locations, most of the 'very satisfied' are urban residents. Even more clearly, age appears to be a strong predictor. It is notable that a radical attitude appears to come with advancing age, rather than the more common notion that younger people are more radical and older people more conservative. This begs the question, whether there are particular aspects of life experience that lead to increased dissatisfaction with the federal system. From a demographic perspective, it is significant that as older age groups increase as a proportion of the Australian population, the proportion of citizens interested in supporting change to the system can also be presumed to increase. 
Table 3.10. Attitudes to three-tier system by gender (NSW) (number of respondents)

\begin{tabular}{l|cc} 
& Very satisfied & Not at all satisfied \\
\hline Male & 13 & 28 \\
Female & 13 & 26 \\
\hline & 26 & 54
\end{tabular}

Table 3.11: Attitudes to three-tier system by period of residence at current place of living (NSW) (\% and number of respondents)

\begin{tabular}{l|cc} 
& Very satisfied & Not at all satisfied \\
\hline Less than 10 yrs & $13(50 \%)$ & $21(40 \%)$ \\
$10-25$ years & $7(27 \%)$ & $20(38 \%)$ \\
More than 25 & $6(23 \%)$ & $12(22 \%)$ \\
\hline & $26(100 \%)$ & $53(100 \%)$
\end{tabular}

Table 3.12: Attitudes to three-tier system by level of completed education (NSW) (number of respondents)

\begin{tabular}{l|cc} 
& Very satisfied & Not at all satisfied \\
\hline School only & 12 & 27 \\
Post-school & 15 & 27 \\
\hline & 27 & 54
\end{tabular}

Table 3.13: Attitudes to three-tier system by rural/urban place of residence (NSW) (number of respondents)

\begin{tabular}{l|cc} 
& Very satisfied & Not at all satisfied \\
\hline Urban & 18 & 26 \\
Rural & 8 & 28 \\
\hline & 26 & 54
\end{tabular}

Table 3.14: Attitudes to three-tier system by age (NSW) (number of respondents)

\begin{tabular}{l|cc} 
Age (years) & Very satisfied & Not at all satisfied \\
\hline $18-19$ & 2 & 0 \\
$20-29$ & 4 & 8 \\
$30-39$ & 4 & 7 \\
$40-49$ & 4 & 6 \\
$50-59$ & 5 & 16 \\
$60+$ & 8 & 17 \\
\hline & 27 & 54
\end{tabular}


Given the insignificance of most of these differences, however, another means of exploring the demographic basis of citizens' views is to compare those respondents who support the more radical scenarios for the future, against the remainder of the sample. In this case, we can compare the $57 \%$ of NSW respondents who preferred the scenarios involving new 'regional' governments, either instead of (scenario C) or in addition to (scenario D) the current states, with all other respondents. In particular, we can look to these respondents as favouring institutional options that explicitly reflect an alternative concept of 'regionalism', by strengthening public institutions of governance at this regional level - however defined, and irrespective of other implications for the political system.

Nevertheless when it comes to location, gender, and education, similar results prevail. As already noted, there is little geographic variation in preferences, with rural respondents only slightly more likely than urban ones to prefer the 'regionalist' options. The 'regionalists' were also only slightly more likely to take a poor view of state governments than the remainder. Table 3.15 suggests that those choosing a regional option are slightly more likely to be male than female. Table 3.16 shows that the 'regionalists' appear slightly better educated, being equally divided in education levels whereas a majority of the remainder have only school education - but the difference is slight. On the question of age, unlike satisfaction with the federal system, there is no significant difference between these groups (Table 3.17). This again tends to reinforce the assumption that that the capacity to envisage or support change is not dependent on active dissatisfaction.

Table 3.15: Support for 'regional' options by gender (NSW) (per cent of respondents)

\begin{tabular}{l|cc} 
& Respondents preferring options C or D & Other respondents \\
\hline Male & 50.5 & 45.9 \\
Female & 49.5 & 54.1 \\
\hline & $100.0(\mathrm{n}=297)$ & $100.0(\mathrm{n}=205)$
\end{tabular}

Table 3.16: Support for 'regional' options by level of education (NSW) (per cent of respondents)

\begin{tabular}{l|cc} 
& Respondents preferring options C or D & Other respondents \\
\hline School only & 51.5 & 56.4 \\
Post-school & 48.5 & 43.6 \\
\hline & $100.0(\mathrm{n}=297)$ & $100.0(\mathrm{n}=202)$
\end{tabular}


Table 3.17: Support for 'regional' options by age (NSW) (per cent of respondents)

\begin{tabular}{l|cc} 
& Respondents preferring options C or D & Other respondents \\
\hline $\mathbf{1 8 - 1 9}$ & 1.0 & 0.5 \\
$\mathbf{2 0 - 2 9}$ & 8.4 & 10.2 \\
$\mathbf{3 0 - 3 9}$ & 16.5 & 17.1 \\
$\mathbf{4 0 - 4 9}$ & 27.3 & 23.4 \\
$\mathbf{5 0 - 5 9}$ & 21.5 & 17.1 \\
$\mathbf{6 0}+$ & 25.3 & 31.2 \\
\hline & $100.0(\mathrm{n}=297)$ & $100.0(\mathrm{n}=205)$
\end{tabular}

With views of the federal system and different constitutional preferences so evenly spread throughout the population, it is necessary to drill even further into the demographic data in order to identify clearer potential determinants of which citizens are likely to hold particular preferences. Other data collected included the nature of respondents' employment, and their level of civic engagement either through some form of government-related committee or certain types of community organisations. One clue that these data might finally reveal more information is contained in the findings above, that dissatisfaction with the current federal system appears to increase with age; and that preferences for 'regionalist' options might increase with level of education. If it is true that citizens' views of the federal system are determined by particular aspects of their life experience, some indication of this should also emerge from the data on employment and civic engagement.

Table 3.18 compares support for the 'regionalist' options and the remainder, according to the nature of respondents' employment. Immediately differences emerge. The two sets of options are equally likely to be supported by private employers and the self-employed, and by those in private sector employment. However, the 'regionalist' options are significantly more likely to be supported by the 112 respondents employed in government; and significantly less likely to be supported by those not in any employment at all. These data also reveal an even more specific and surprising result - the government employees most likely of all to prefer the 'regionalist' options were state government employees. 
Table 3.18: Support for 'regional' options by employment (NSW) (per cent and number of respondents)

\begin{tabular}{l|c|c|c|c} 
& $\begin{array}{c}\text { Respondents } \\
\text { preferring option } \\
\text { C1 }\end{array}$ & $\begin{array}{c}\text { Respondents } \\
\text { preferring option } \\
\text { D }\end{array}$ & $\begin{array}{c}\text { Respondents } \\
\text { preferring options } \\
\text { C or D }\end{array}$ & $\begin{array}{c}\text { All other } \\
\text { respondents }\end{array}$ \\
\hline Employees & $\%(\mathrm{n})$ & $\%(\mathrm{n})$ & $\%(\mathrm{n})$ & $\%(\mathrm{n})$ \\
Government - Federal & 2.8 & 4.7 & 3.0 & 1.5 \\
State & 20.1 & 16.7 & 19.5 & 8.8 \\
Local & 2.4 & 6.3 & 3.0 & 3.4 \\
Other & 2.4 & 4.7 & 2.7 & 0.5 \\
Subtotal & 27.7 & 31.3 & 28.3 & 13.7 \\
\hline Non-government & 23.7 & 39.6 & 26.3 & 28.3 \\
\hline All employees & $51.4(128)$ & $70.8(34)$ & $54.5(162)$ & $41.9(86)$ \\
\hline Employer / self-employed & $14.5(36)$ & $12.5(6)$ & $14.1(42)$ & $13.7(28)$ \\
Unemployed and seeking work & $2.4(6)$ & $0.0(0)$ & $2.0(6)$ & $4.4(9)$ \\
Not employed and not seeking & $31.7(79)$ & $16.7(8)$ & $29.3(87)$ & $40.0(82)$ \\
work (incl. retired, home duties) & & & & \\
\hline & $100.0(249)$ & $100.0(48)$ & $100.0(297)$ & $100.0(205)$
\end{tabular}

This is further demonstrated by Figure 3.19, showing the spread of support for all options according to employment type. Overall, the 112 government employees captured by our sample are the most likely to have a view (with the lowest rate of 'don't knows'), but the least likely to believe that the federal system should remain the same. Directly contrary to the expectation that employment by state government would be associated with an opposition to change, and especially to change to the role of state governments themselves, 50 of the 75 state government employees in our sample (i.e. 66.7\%) preferred the option most consistent with total abolition of their own employer - the single highest identifiable source of support for this option. The capture of a sizeable group of state government employees in the sample was somewhat accidental, since this was not a determining feature of the way the sample was drawn. It is clearly not a representative group - only 22 of these 75 respondents were from the urban zone, and their support for the 'two-tiered' option was lower $(56.5 \%$, as against $71.2 \%$ support among rural state government employees). However, even the result from urban state employees was well above the state mean. The views of state employees overall seemed less likely to have been determined by temporary party-political factors, with $53.3 \%$ of these respondents indicating they would retain 'exactly the same' or 'much the same view' of the relative performance of different levels of governments in the event of electoral change (as against $46.4 \%$ of all respondents), and only $10.7 \%$ indicating they would have a 'completely different view' (as against $15.1 \%$ of all respondents). 
Figure 3.19. Preferred federal systems by employment (NSW)
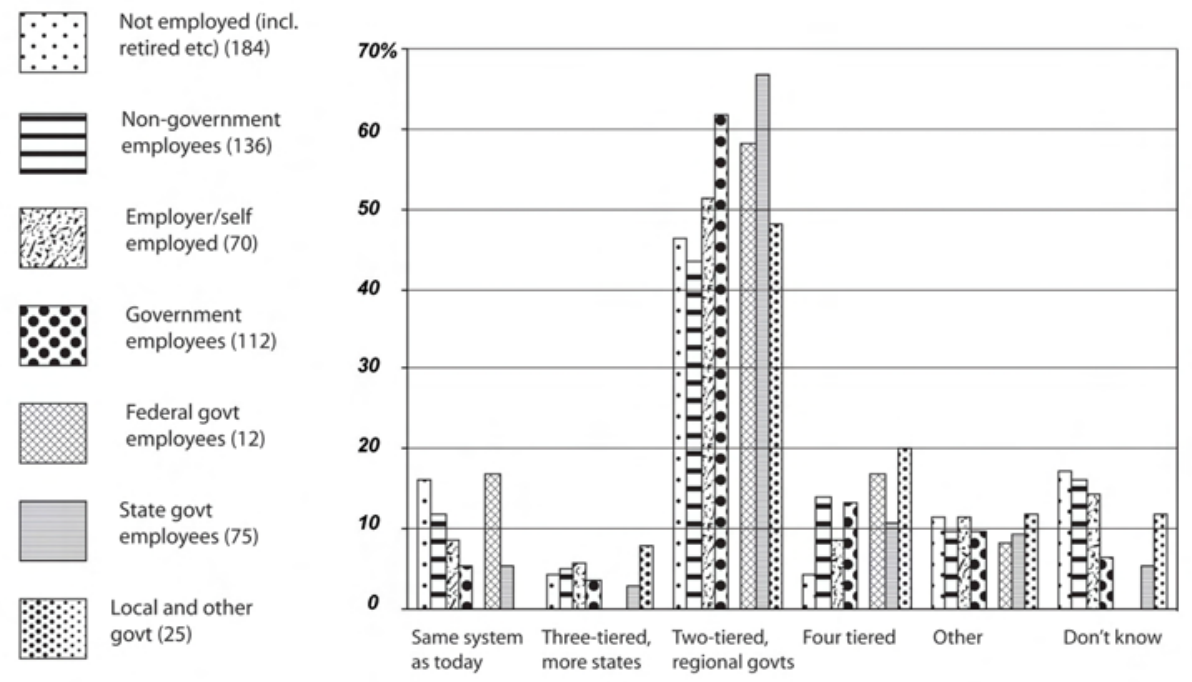

Table 3.20 and Figure 3.21 set out the equivalent results for the 57 respondents who indicated they were 'an active member of any organisation involved with regional development or resource management', and the 29 respondents who indicated they were an 'active member of any official government committee or advisory group'. Examples given of the former were Landcare and other local environment groups, and Chambers of Commerce and economic development groups. The latter included federal, state or local committees, or a committee involving a combination of governments. There is almost certainly overlap between these groups, as well as overlap between the second group and the government employees noted earlier; but as shown, the results do differ. Members of organisations and committees are typically around twice as likely as non-members to favour one of the 'regionalist' options, notably the option of a 'two-tiered' restructure. Like government employees, members of organisations and committees are also more likely to have a view, with very low rates of 'don't know' responses. 
Table 3.20: Support for 'regional' options by civic engagement (NSW) (per cent and number of respondents)

\begin{tabular}{l|r|r|r|r}
$\mathbf{3 . 2 0 a}$ & $\begin{array}{c}\text { Respondents } \\
\text { preferring option } \\
\text { C }\end{array}$ & $\begin{array}{c}\text { Respondents } \\
\text { preferring option } \\
\text { D }\end{array}$ & $\begin{array}{c}\text { Respondents } \\
\text { preferring } \\
\text { options C or D }\end{array}$ & $\begin{array}{c}\text { All other } \\
\text { respondents }\end{array}$ \\
\hline Organisation members & 14.1 & $\%$ & $\%(\mathrm{n})$ & $\%(\mathrm{n})$ \\
\hline Non-members & 85.9 & 12.5 & $13.8(41)$ & $7.8(16)$ \\
\hline 3.20b & 100.0 & 100.0 & $100.0(297)$ & $100.0(205)$ \\
\hline Committee members & 7.2 & 8.3 & $7.4(22)$ & $3.4(7)$ \\
Non-members & 92.8 & 91.7 & $92.6(275)$ & $96.6(198)$ \\
\hline & 100.0 & 100.0 & $100.0(297)$ & $100.0(205)$
\end{tabular}

Figure 3.21. Preferred federal systems by civic engagement (NSW)

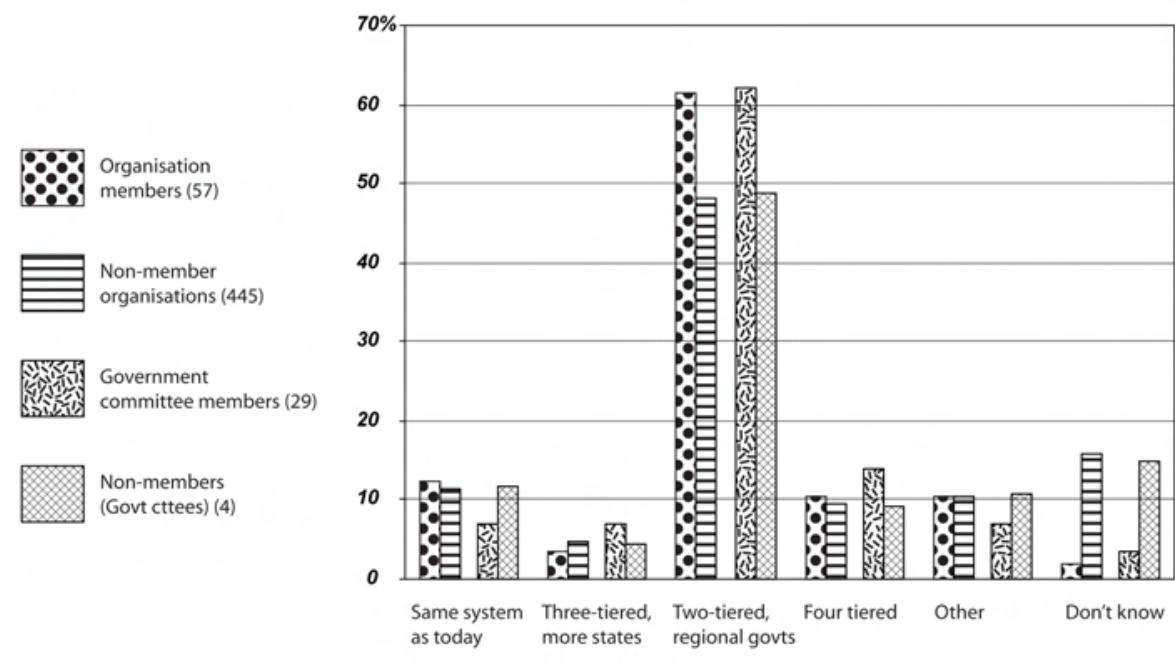

These differences tend to confirm that while support for change and adaptation of the federal system is widespread, it is particularly associated with life experiences, including not simply age but different types of employment and levels of civic engagement. The logical question to ask, highlighted by the surprising response from the majority of state government employees, was whether particular types of employment and civic engagement would be more or less likely to lead citizens to favour institutional change. In particular, returning to the overall question of whether change based on a greater recognition of regionalism has a basis in Australian political culture, it is sensible to ask whether those citizens who say they would prefer such change are speaking from a position of naivety or relative ignorance about the existing federal system. The results based on age and education, explored further above, tended to suggest otherwise (Brown et al 2006: 297-298). So did results from the 
earlier Queensland survey, which revealed that at least some groups of citizens with heightened direct experience of the workings of government - officials and employees of local government - were more rather than less likely to support reform than the average, less involved citizen (Brown 2002b: 29).

These results confirm that, whether or not related to active dissatisfaction with the federal system, preferences for change that are consistent with some of Australia's longest-running federal political debates form the views neither of a small fringe minority, nor of citizens with any particularly uninformed or simplistic basis for their opinions. As well as being held very broadly across the community, these convictions about the desirability of reform are strongest among those we would expect to know most about the practical realities of how federalism works, even when reform (if it happened to them) would require upheaval of their own professional world.

\section{In conclusion: a new window on the feasibility of reform}

Based on surveys of public opinion in Queensland and, more recently, in NSW, this chapter has shown that both critical attitudes of federalism and more radical preferences for change - two things that are not necessarily directly related are widespread features of Australian society and not readily confined to particular types of regions or social groups. In fact, where the more radical preferences for change are strongest, is among those citizens who are most directly engaged in the economy (by way of employment), and particularly directly involved in government employment, as well as those most directly engaged in governance more generally through community organisations or committees. These respondents also confirm that opinions about the future development of the federal system are not necessarily as speculative or unsophisticated as might otherwise be assumed, not only through their greater knowledge but the greater certainty of their responses. Furthermore, it seems not only that many more Australians are interested in reform than previously understood, but that many also accept it as inevitable.

Given the dynamic state of developments in governance, what does this suggest about the realms of 'the possible' for institutional reform? The most important results are that in both Queensland and NSW, the public appetite for reform appears to be alive and well and widespread throughout the community. In both these states, the concept of 'the region' as an alternative scale of governance also has considerable popular currency, including in urban regions; and there is a widespread appetite for political and constitutional strengthening of governance at this level. The absence of major locational, demographic and sociological differences in the attachment to the specific options for achieving this, also indicate that debate about the specific institutional path is relatively wide open. Neither political analysts, nor political leaders, have any reason to assume that citizens are incapable of or disinterested in participating in a debate about an 
improved system. On the contrary, there is every sign that most Australians harbour an abiding conviction that a better system can and should evolve in response to current pressures and do so in a way which delivers a more truly federal, politically-regionalised approach to governance. Perhaps most importantly, in these states there is little sign of public interest in a debate about half-measures, or options which represent artificial compromises between the historical theory of federalism as played out in Australia (for example, based on the idea that regions can be better served by the creation of new states) and more practical ideas about how government should work. Citizens appear more interested in options that most past political leaders and commentators would define as quite radical. This provides a rare opportunity for policy-makers with any temptation to be visionary.

In terms of institutional options, the answers do not necessarily lie in the particular scenarios offered in these surveys. For any number of reasons, including some outlined above, Australia is no more likely to ever move to a totally 'two-tiered' version of federalism - the scenario preferred by many respondents - than it is to stay exactly the same. In practical terms, despite the low level of public support for the creation of new states (as presently understood), constitutional reality may dictate that this is the easiest -and possibly the only - way to create any kind of permanent new regional governments, if these are to be formally entrenched. Similarly, for state governments to join with other tiers in the development of an agreed framework of regionalised governance is immediately more viable than other options, because this could be done without any constitutional change. As a result the most accurate predictions are perhaps those made by the $15 \%$ of Queensland respondents, and $13.7 \%$ of NSW respondents (weighted), that Australia is destined to continue to develop its fourth tier of regional institutions into a recognisable level of government in its own right, before any thoroughly reformed federal system is likely to emerge. Interestingly, in the NSW survey this prediction was backed by $15.2 \%$ of all government employees, and $20.7 \%$ of all members of government-related committees, irrespective of whether they actually see this as a desired outcome. In this respect, even when seen through the eyes of public opinion, the options for developing a federal system are not simplistic but complex.

Is change to the federal system politically viable? The full answer depends on national research of a similar kind, now in progress. However the findings above suggest that with suitable leadership and an appropriate process, public opinion is an asset to be tapped rather than necessarily a barrier to change. As with federation itself, it may be public opinion that leads the way, if in the eyes of the broader community the responsiveness of political elites is left wanting. 


\section{References}

ASSA (2003). Australian Survey of Social Attitudes Dataset 2003. Source: Australian Social Science Data Archive, Research School of Social Sciences, The Australian National University. <http:||assda.anu.edu.au> (2005). Australian Survey of Social Attitudes Dataset 2005. Source: Australian Social Science Data Archive, Research School of Social Sciences, The Australian National University. <http: \|assda.anu.edu.au>

Brown, A. J. (2002a). 'After the party: public attitudes to Australian federalism, regionalism and reform in the 21 st century' Public Law Review 13(3): 171-190.

(2002b). 'Subsidiarity or subterfuge? Resolving the future of local government in the Australian federal system.' Australian Journal of Public Administration 6I(4): 24-42.

Brown, A. J., I. Gray and D. Giorgas (2006), 'Towards a more regional federalism: rural and urban attitudes to institutions, governance and reform in Australia', Rural Society I6(3): 283-302.

Galligan, B. (1995). A federal republic: Australia's constitutional system of government. Cambridge University Press.

Howard, J. (1991). As quoted in The Australian, 9 November 1991; see L. Tanner (1999), Open Australia, Pluto Press, Sydney, pp.207-208.

(2002). 'Address to the National Assembly of Local Government', Alice Springs, as quoted by J.Hassan, 'Two tiers out of three ain't bad: Howard', Government News, December 2001 / January 2002.

(2005). 'Reflections on Australian Federalism', Speech to the Menzies Research Centre, Melbourne, 11 April 2005.

\section{ENDNOTES}

1 The full text of the questionnaire and further information on the project is available at www.griffith.edu.au/federalism. 